\title{
Mesenchymal stem cell therapy for attenuation of scar formation during wound healing
}

Wesley M Jackson 1,2, Leon J Nesti, ${ }^{1,3}$ and Rocky S Tuan ${ }^{4 *}$

\begin{abstract}
Scars are a consequence of cutaneous wound healing that can be both unsightly and detrimental to the function of the tissue. Scar tissue is generated by excessive deposition of extracellular matrix tissue by wound healing fibroblasts and myofibroblasts, and although it is inferior to the uninjured skin, it is able to restore integrity to the boundary between the body and its environment. Scarring is not a necessary process to repair the dermal tissues. Rather, scar tissue forms due to specific mechanisms that occur during the adult wound healing process and are modulated primarily by the inflammatory response at the site of injury. Adult tissue-derived mesenchymal stem cells, which participate in normal wound healing, are trophic mediators of tissue repair. These cells participate in attenuating inflammation in the wound and reprogramming the resident immune and wound healing cells to favor tissue regeneration and inhibit fibrotic tissue formation. As a result, these cells have been considered and tested as a likely candidate for a cellular therapy to promote scar-less wound healing. This review identifies specific mechanisms by which mesenchymal stem cells can limit tissue fibrosis and summarizes recent in vivo studies where these cells have been used successfully to limit scar formation.
\end{abstract}

\section{Introduction}

Adult human skin is limited in its ability to repair itself following injury that penetrates beyond the epidermis. The cutaneous wounding healing process results in the formation of a scar that is composed of excess extracellular matrix (ECM) in the place of the normal dermal tissue. Besides having a different visual appearance,

*Correspondence: rst13@pitt.edu

${ }^{4}$ Center for Cellular and Molecular Engineering, Department of Orthopaedic

Surgery, University of Pittsburgh School of Medicine, 450 Technology Drive,

Room 221, Pittsburgh, PA 15219, USA

Full list of author information is available at the end of the article which can be undesirable, the tissue in the vicinity of the scar does not function like the surrounding skin, as it does not contain many of the structures that are native to the dermis, including sebaceous glands, hair follicles and sensory nerve receptors [1]. The scar tissue is also limited to approximately $80 \%$ of the tensile strength of the surrounding skin [2] and results in a weak point that is susceptible to re-injury. However, scar formation is not required for cutaneous healing, as wound healing occurs in the absence of scarring throughout most of fetal development (reviewed in [3]). There has been considerable scientific effort to understand the mechanism of cutaneous scar formation with the goal of developing potential therapies to promote scar-less wound healing.

Despite the deleterious consequences of fibrosis and scar tissue formation, current treatments to promote scar-less wound healing are primarily limited to the standard principles of wound management. These include the use of topical antibiotics and sterile dressing in order to minimize the risk of infection to advance the wound healing process through the inflammatory phase and into the cellular proliferation and remodeling phases [1], where functional tissue regeneration can occur. Irrigation and debridement of the wound may be applied as necessary to remove foreign bodies and necrotic tissue that can promote tissue inflammation [4]. If the inflammatory phase is prolonged, the pro-inflammatory mediators will direct the wound healing cells, such as myofibroblasts and fibrocytes, in generating the non-functional, void-filling tissue that will result in the formation of a scar [5].

Mesenchymal stem cells (MSCs), which appear to be a native constituent of the wound bed [6], have emerged as an alternative to the standard pharmaceutical treatment modalities. These cells are important trophic mediators to promote tissue regeneration and can be readily derived from a variety of autologous or allogeneic adult tissues, as well as from commercial providers [7]. The versatility of these cells has made them an attractive candidate for clinical translation in a variety of therapeutic applications. In particular, MSCs may offer the means of recapitulating several mechanisms that are sufficient for inhibition of scar formation in skin wounds (Figure 1). 


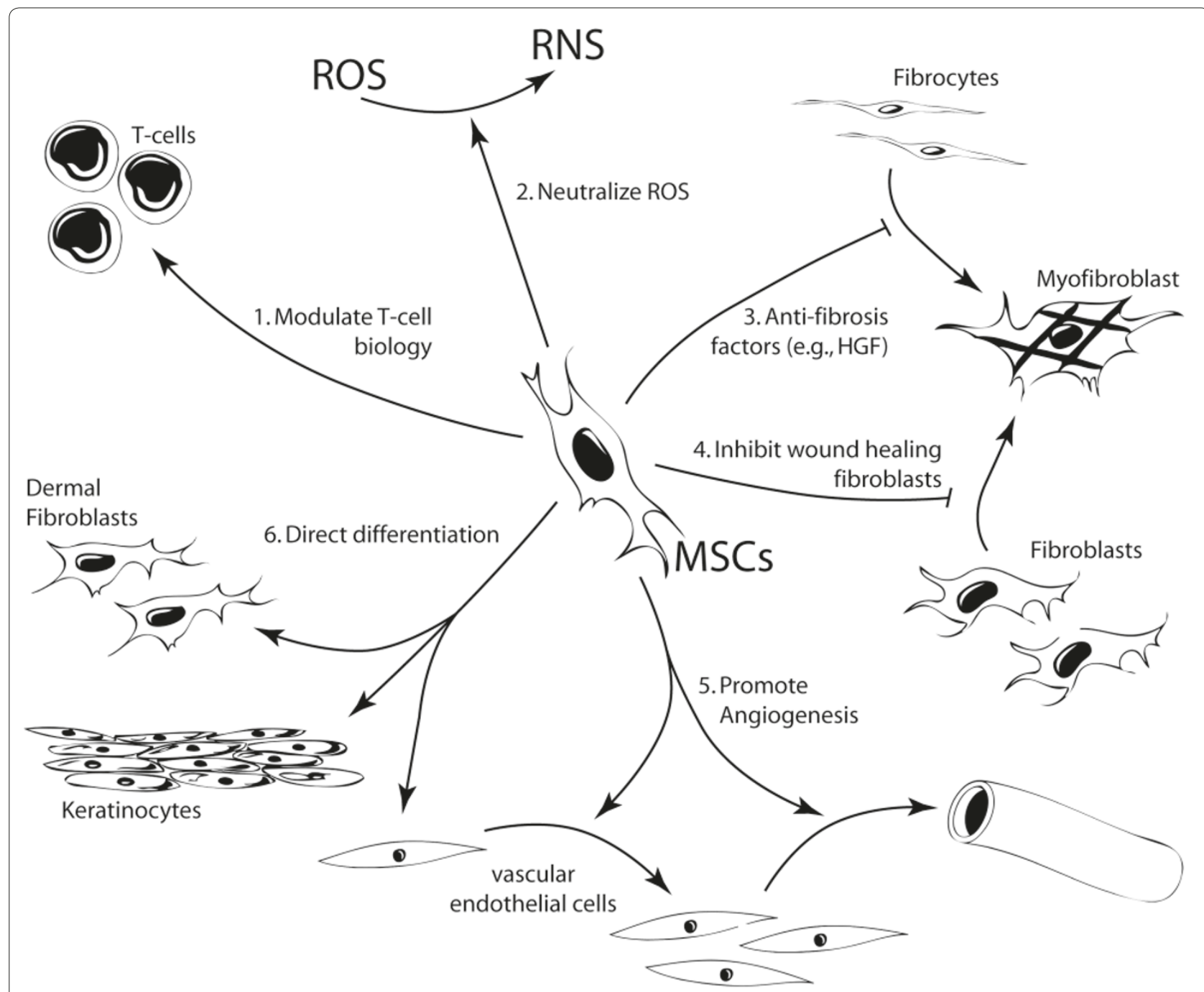

Figure 1. Mesenchymal stem cells can influence cutaneous regeneration by multiple distinct mechanisms acting on multiple cell types. HGF, hepatic growth factor; MSC, mesenchymal stem cell; RNS, reactive nitrogen species; ROS, reactive oxygen species.

This review will provide an overview of current research into cutaneous wound healing with an emphasis on specific mechanisms by which MSCs may enhance functional tissue regeneration.

\section{Anti-scarring mechanisms of mesenchymal stem cells}

MSCs are a broadly generalized cell type that can be found in a variety of adult tissues throughout the body and exhibit specific characteristics when cultured in vitro [8]. In particular, MSCs must be capable of robust ex vivo expansion and maintain the ability to differentiate into osteoblasts, adipocytes and chondrocytes. Many recent studies have also demonstrated that MSCs exhibit a number of trophic functions to enhance tissue regeneration, such as promoting angiogenesis and modulating the inflammatory response (reviewed in [9]). Originally harvested in the adherent fraction of cells in a bone marrow aspirate [10], MSCs have since been identified in a variety of other adult tissues, including adipose tissue $[11,12]$, the marrow space of long bones $[13,14]$, trabecular bone chips [15-17], periosteum [18,19], synovial fluid [20-22], periodontal ligament [23,24], palatine tonsil [25], parathyroid gland [26], fallopian tube [27] and traumatized muscle tissue $[28,29]$. MSCs have also been harvested from prenatal tissues that are lost as a result of development, such as umbilical cord [30,31], umbilical cord blood/Wharton's Jelly [32,33] and primary tooth dental pulp [34,35]. There is a growing body of evidence to suggest that a substantial fraction of the cells exhibiting the in vitro characteristics of MSCs arise from vascular pericytes in vivo [36], suggesting that there is a common 
precursor cell type in a wide variety of adult and fetal tissues. Given their regenerative functions, availability and potential for cell banking [37], there is immense interest in developing cellular therapies based on autogenous or allogeneic MSCs

The basic biology of wound healing has been extensively studied (reviewed in [1]), and MSCs are clearly capable of responding and modulating their function when exposed to the cells and biochemical factors that are characteristic of an injury environment. Human MSCs migrate preferentially to regions of inflammation [38] and express several chemokine receptors that are necessary to coordinate their homing ability [39]. Furthermore, MSCs have demonstrated chemotaxis toward a variety of wound healing cytokines in vitro, including platelet-derived growth factor, insulin-like growth factor-1, IL-8 and TNF $\alpha[40,41]$. These data suggest that bone-marrow-derived MSCS or endogenous cells resembling MSCs, such as pericytes, are likely to migrate to and participate in the response to tissue injury.

There is ample evidence based on murine models of injury and disease to demonstrate that systemically administered allogeneic MSCs are capable of homing to and engrafting at the site of tissue damage [42,43]. Several recent studies have further quantified the extent of bone marrow-derived MSC involvement during wound healing. A chimeric mouse model was developed to evaluate MSCs by lethally irradiating female C57BL/6 mice, followed by replacement with fluorescently labeled MSCs from male BALB/c mice in the bone marrow [44]. These mice demonstrated gradual engraftment of the donor cells in the dermis as the bone marrow-derived MSCs participated in the process of dermal regeneration, and fluorescent cells in the regenerated tissue also exhibited markers of dermal fibroblasts. Furthermore, the number of green fluorescent protein-labeled cells in the dermis increased approximately $400 \%$ in regions that experienced cutaneous injury [45], suggesting that recruitment from the bone marrow occurred at the site of wound healing. As with other populations of marrow stromal cells, the mobilization of MSCs appears to be dependent on systemic levels of granulocyte-colony stimulating factor (G-CSF), and homing to the site of injury is dependent on local expression of stromal cellderived factor (SDF)-1 [46]. Exogenous administration of either G-CSF or SDF-1 is sufficient to increase MSC recruitment to the site of injury and corresponds to enhanced wound healing at the sites of MSC recruitment.

One likely function of MSCs in the process of wound healing is to regulate the function of the leukocytes that have invaded the tissue in response to injury [47,48]. Once the MSCs enter the inflammatory environment, their immunomodulatory phenotype becomes activated by IFN $\gamma$, TNF $\alpha$ and IL-1 $\beta$ [49]. The ability of MSCs to regulate T-cell recruitment, proliferation and activity is well documented $[49,50]$. There is also evidence that MSCs are capable of suppressing the proliferation of B cells [51] and natural killer cells [52], thereby ameliorating the acute immune response to injury. By attenuating the function of these cell types, the MSCs would likely reduce the pro-fibrotic responses that can occur coincident with prolonged inflammation during wound healing [53,54]. However, a variety of other likely mechanisms by which MSCs could suppress fibrosis and the formation of scar tissue are discussed below.

\section{Modulation of macrophage and T-cell function during wound healing}

During the transition between the inflammatory and proliferation stages of wound healing, macrophages resident in the wound undergo a change in phenotype to an alternative activation (M2) state. IL-4 and IL-13 are the archetypical activators of the M2 phenotype [55], and there is evidence that IL-4 may be produced by mast cells that migrate from the margins into the wound bed during this stage of healing [56]. The precise alternative phenotype of the macrophages during cutaneous wound healing has not been fully defined, as the M1/M2 macrophage model varies somewhat between tissue types [57]. However, alternative macrophage activation is generally characterized by decreased expression of pro-inflammatory cytokines accompanied by an increase in antiinflammatory signaling [57]. This shift in inflammatory modulation is accompanied by the expression of cytokines that promote tissue regeneration, such as heparin bound epidermal growth factor (HB-EGF), fibroblast growth factor (FGF)-2 and vascular endothelial growth factor (VEGF) [1]. HB-EGF signaling to keratinocytes provides additional stimulus to promote re-epithelialization and the formation of a new epidermal layer [58]. FGF-2 and VEGF promote the proliferation and migration of fibroblasts and endothelial cells into the fibrin clot [59].

The inflammatory environment of the wound activates the MSCs to initiate their immunomodulatory functions, including an increase in cyclooxygenase-2 activity and up-regulation of prostaglandin $\mathrm{E}_{2}$ (PGE2) expression [60], which has multiple fibroregulatory effects on the wound. In particular, PGE2 plays a necessary role in the immunoregulatory mechanism of the MSCs to inhibit the expression of IL-2 [61] and attenuate mitogenesis and proliferation of $\mathrm{T}$ cells in the wound [62]. PGE2 is also a co-factor in the transition from $\mathrm{T}_{\mathrm{H}} 1$ cells into $\mathrm{T}_{\mathrm{H}} 2$ cells [63], corresponding to a decrease in the expression of INF $\gamma$ and up-regulation of IL-4 by the effector T cells [64]. The decreasing ratio of IFN $\gamma$ relative to IL-4 in the wound promotes functions that are associated with the alternative activation of macrophages [65], which favor wound 
healing over inflammation and promote the activity of mesenchymal cells during the proliferation stage (reviewed in [55]).

PGE2 expression results in other indirect fibroregulatory effects by interacting with immune cells that are resident in the wound. In response to PGE2, T cells [66] and macrophages [60] become reprogrammed and begin to express higher levels of IL-10, an important antiinflammatory cytokine with multiple functions to limit or attenuate the inflammatory mechanism of immune cells [67]. IL-10 is a powerful inhibitor of neutrophil invasion into the wound and prevents further oxidative tissue damage from their release of reactive oxygen species (ROS) [68]. IL-10 may also have direct effects on fibrosis by down-regulating the expression of transforming growth factor (TGF) $\beta 1$ in macrophages and T cells [67], and reprogramming wound fibroblasts to favor ECM remodeling by up-regulating the expression of matrix metalloproteinases (MMPs) and down-regulating the expression of collagens [69]. IL-10 also prevents excessive collagen deposition by attenuating the expression of proinflammatory cytokines in the wound, such as IL-6 and IL-8 [70]. As a result of these mechanisms, expression of IL-10 contributes to a resolution of the inflammatory stage and acceleration of the wound into the proliferation stage [71]. The role of IL-10 in fibroregulation has been verified by demonstrating that scar-less wound healing can be abrogated in fetal mice by knocking out IL-10 [70], and then over-expression of IL-10 in post-natal skin generates a permissive environment where wound healing is more likely to occur with the absence of scar formation [72].

\section{Neutralization of reactive oxygen species in the wound}

MSCs substantially up-regulate the expression of inducible nitric oxide synthase in response to their interaction with $\mathrm{T}$ cells in a pro-inflammatory environment. Nitric oxide is complementary to PGE2 for the inhibition of T-cell proliferation [73], but there is evidence that it has other, more direct mechanisms to prevent the formation of scar tissue. ROS secreted by neutrophils, including superoxide, hydrogen peroxide and alkyl peroxides, are highly cytotoxic compounds used to achieve wound sterility, but these ROS are also intensifiers of collagen deposition [74]. Prolonged ROS exposure during wound healing leads to enhanced fibrogenesis and accumulation of fibrotic tissues through a mechanism involving membrane lipid oxidation and induction of TGF $\beta 1$ [75]. Nitric oxide produced by MSCs in the wound can scavenge ROS to produce reactive nitrogen species, such as peroxynitrite [76]. Although these reaction products are also oxidative and cytotoxic, they react more slowly than their associated ROS [77] and prevent oxidative damage to DNA and membrane lipids [76]. A recent study has demonstrated that inducible nitric oxide synthase expression is sufficient to alter the ROS/RNS balance to prevent the formation of fibrotic tissues [78].

\section{Mesenchymal stem cells produce anti-fibrotic factors}

MSCs secrete a variety of cytokines and growth factors that have anti-fibrotic properties, including hepatocyte growth factor (HGF), IL-10 and adrenomedullin [79-81]. The anti-fibrotic properties of IL-10 have been described earlier in this paper. HGF has also been shown to attenuate fibrosis and scar formation through a variety of mechanisms. Fibroblasts respond to HGF by downregulating their expression of TGF $\beta 1$ [82], collagen type I [83] and collagen type III [82], as HGF receptor binding antagonizes downstream signaling cascades [83] and promotes the nuclear exclusion of SMAD 3, the transcription factor associated with many pro-fibrotic genes [84]. HGF also stimulates the up-regulation of MMP-1, MMP-3 and MMP-13 expression in fibroblasts [85], thereby promoting the turnover of the ECM. In addition to fibroregulation of fibroblast function, HGF promotes keratinocyte migration, proliferation [86], and upregulates their expression of VEGF-A [87]. Therefore, the expression of HGF contributes to the generation of a high-quality, well-vascularized granulation tissue and enhanced re-epithelialization of the wound [86].

There is also evidence for an additional anti-fibrotic mechanism of HGF by contributing to the inhibition of myofibroblast differentiation. Although contraction may facilitate re-epithelialization by narrowing the wound margin for alignment of ECM components [1], this process does not necessarily require fully differentiated myofibroblasts. Fetal wound healing occurs in the near absence of myofibroblasts [88]. Furthermore, during oral epithelial wound healing, which is characterized by high levels of HGF and keratinocyte growth factor, rapid wound contraction occurs in the absence of robust myofibroblast commitment and yields less scar tissue compared to cutaneous wound healing [89]. TGF $\beta 1$ is a potent driver of myofibroblast differentiation, and high levels of TGF $\beta 1$, which is often related to a prolonged acute inflammatory response, can lead to over-contraction, formation of tight collagen bundles and excessive matrix deposition with the visual appearance of a scar. In diseases caused by excessive fibrosis, HGF appears to resist the differentiation of fibroblasts into myofibroblasts [90], thereby limiting the pro-fibrotic functions that are characteristic of these cells.

\section{Mesenchymal stem cells enhance dermal fibroblast function}

During the proliferation stage of wound healing, dermal fibroblasts from the wound margin proliferate and migrate into the wound, generate granulation tissue, and 
begin to remodel the wound matrix to generate new dermal tissue. However, there are additional sources of fibroblasts that may be recruited to participate in these wound repair processes, as is warranted by the extent of the injury. In response to elevated levels of TGF $\beta 1$, endothelial cells from damaged blood vessels may be encouraged to undergo epithelial-to-mesenchymal transition (EMT) and become wound healing myofibroblasts [91]. Fibrocytes may also be recruited into the wound due to prolonged inflammatory response or when the wound matrix cannot be rapidly converted into granulation tissue [92], and the fibrocytes rapidly differentiate into myofibroblasts in the presence of TGF $\beta 1$ and T cells [93]. Although these generic wound-healing fibroblasts may be needed to restore integrity of the skin after some types of injury, they produce excessive amounts of ECM compared to dermal fibroblasts, and they are more likely to yield a tissue with the visual appearance of a scar [94]. MSCs resident in the wound can inhibit EMT by producing HGF [95] and PGE2 [96], and they can resist myofibroblastic differentiation as described in the previous section. MSCs also produce paracrine factors that promote specific wound healing functions of dermal fibroblasts [97]. These combined mechanisms enable MSCs to regulate the cells populating the wound to favor resident wound healing cells to produce an ECM that more closely resembles the surrounding dermal tissue.

\section{Mesenchymal stem cells promote angiogenesis and vascular stability}

Angiogenesis is a necessary process during the proliferation phase of wound healing to provide the fibroblasts with sufficient nutrient supply for the production of a provisional granulation matrix [98]. Failure to generate an adequate microvascular network leads to deficiencies in wound closure and may develop into a chronic non-healing wound. Equally important is the need to stabilize the provisional vessels as the tissue remodels and to form a permanent vascular network. In addition to macrophages and fibroblasts, MSCs produce basic FGF and VEGF-A, which provide powerful mitogenic cues to promote proliferation, migration and differentiation of microvascular endothelial cells $[99,100]$. MSCs also express paracrine factors to promote vascular stability and vasoprotection [101,102], including adrenomedullin [103]. It has been hypothesized that these functions are unique to MSCs due to their possible perivascular origin, and they are able to exploit these functions to recreate their perivascular niche as the process of vasculature remodeling is concluded [104]. Enhancement of vascular formation by bone-marrowderived MSCs has been demonstrated in vitro [105] and to facilitate the development of long-lasting functional vasculature as perivascular progenitor cells [106].
Mesenchymal stem cells differentiate into dermal cell types MSCs are typically characterized based on their ability to differentiate into osteoblasts, adipocytes and chondrocytes in vitro. It is likely that MSCs in the wound environment may assume a phenotype that resembles that of the resident dermal fibroblasts or myoblasts, and this differentiation process has been recapitulated in vitro [107]. More interesting and relevant is recent evidence demonstrating that MSCs may trans-differentiate to epidermal cells, keratinocytes and microvascular endothelial cells under defined conditions in vitro $[39,108,109]$. Finally, MSCs may also trans-differentiate into keratinocytes under conditions that allow them to interact with native epidermal cells [110]. These studies suggest that MSCs could participate directly in the structural regeneration of dermal and epidermal tissues, thus representing an additional mechanism by which the MSCs may promote cutaneous wound healing.

\section{Conclusions and future perspectives}

In this review, we have highlighted many recent scientific findings that illustrate the cellular mechanism by which MSCs participate in and enhance the process of wound healing with the potential to minimize the formation of scar tissue. Although it is unlikely that MSCs can replicate the mechanisms of scar-less wound healing that occur in fetal dermal tissues, they may still re-initiate or promote some of the processes that characterize fetal wound healing. There is also emerging evidence that MSC phenotype can be polarized by inflammatory environments, and suggests a paradigm for MSC function mirroring similar behavior in $\mathrm{T}$ cells and macrophages [111]. These studies indicate that MSCs respond to inflammatory cytokines by modulating the expression levels of Toll-like receptors, thereby attenuating the immunosuppressive biochemical signaling that is typical of MSC populations [112]. A better understanding of how MSCs interact with and regulate the resident immune cells in the wound will facilitate their clinical translation for wound healing applications.

In a recent review [113], we have summarized the recent pre-clinical and clinical studies designed to evaluate MSCs as a cell therapy to improve wound healing, and a summary of these studies is provided in Table 1. Based on a variety of small and large animal studies, a growing body of evidence suggests that MSCs provide significant benefit during dermal wound healing, as they can (1) accelerate the rate of wound closure and re-epithelialization, (2) improve the quality and strength of the regenerated tissue, (3) recover wound healing pathologies that might otherwise result in a chronic, non-healing wound, and (4) minimize the visual appearance of scar tissue. In spite of these encouraging pre-clinical findings, there are currently only four active clinical trials 
Table 1. In vivo outcomes of wound healing augmented by mesenchymal stem cell therapy

\begin{tabular}{|c|c|c|c|c|c|}
\hline Experimental details & $\begin{array}{l}\text { Accelerated } \\
\text { wound } \\
\text { closure }\end{array}$ & $\begin{array}{l}\text { Improved } \\
\text { tissue } \\
\text { strength }\end{array}$ & $\begin{array}{l}\text { Prevented } \\
\text { chronic } \\
\text { ulceration }\end{array}$ & $\begin{array}{l}\text { Improved } \\
\text { visual } \\
\text { appearance }\end{array}$ & Reference \\
\hline $\begin{array}{l}\text { Murine MSC conditioned medium } \\
\text { Topical delivery } \\
\text { Splinted excisional wounds in mice }\end{array}$ & $\checkmark$ & & & & {$[80]$} \\
\hline $\begin{array}{l}\text { Allogenic and syngenic murine MSCs } \\
\text { Injection into the wound } \\
\text { Excisional wounds in mice }\end{array}$ & $\checkmark$ & & & & [43] \\
\hline $\begin{array}{l}\text { Murine MSCs } \\
\text { Injection into the wound } \\
\text { Excisional wounds in } \mathrm{db} / \mathrm{db} \text { mice }\end{array}$ & $\checkmark$ & & $\checkmark$ & & [116] \\
\hline $\begin{array}{l}\text { Rat ASCs } \\
\text { Injection into the wound } \\
\text { Excisional wounds in diabetic rats }\end{array}$ & $\checkmark$ & & $\checkmark$ & & [117] \\
\hline $\begin{array}{l}\text { Murine MSCs } \\
\text { Injection into the wound margin } \\
\text { Splinted excisional wounds in } \mathrm{db} / \mathrm{db} \text { mice }\end{array}$ & $\checkmark$ & & $\checkmark$ & $\checkmark$ & [110] \\
\hline $\begin{array}{l}\text { Human MSCs } \\
\text { Injection into wound } \\
\text { Incisional wounds in rabbits }\end{array}$ & & $\checkmark$ & & $\checkmark$ & [118] \\
\hline $\begin{array}{l}\text { Human V53/2 MSC cell line } \\
\text { Seeded on collagen scaffolds } \\
\text { Splinted excisional wounds in mice }\end{array}$ & $\checkmark$ & & & $\checkmark$ & [119] \\
\hline $\begin{array}{l}\text { Human MSCs } \\
\text { Incorporated in fibrin spray } \\
\text { Chronic and acute wounds in humans }\end{array}$ & $\checkmark$ & & $\checkmark$ & $\checkmark$ & [120] \\
\hline $\begin{array}{l}\text { Swine MSCs } \\
\text { Injection into the wound } \\
\text { Thermal wounds in mini pigs }\end{array}$ & $\checkmark$ & & & $\checkmark$ & [108] \\
\hline $\begin{array}{l}\text { Murine MSCs } \\
\text { Systemic injection } \\
\text { Excisional wounds in mice }\end{array}$ & $\checkmark$ & & & & [39] \\
\hline $\begin{array}{l}\text { Rat MSCs } \\
\text { Systemic injection } \\
\text { Excisional wounds in rats }\end{array}$ & $\checkmark$ & $\checkmark$ & & & [121] \\
\hline
\end{tabular}

ASC, adipose-derived stem cell; MSC, mesenchymal stem cell.

pertaining to the treatment of dermal wounds with MSCs [114]. This is evidence of several substantial barriers that still exist that limit the clinical translation of MSCs, including a scalable cell-sourcing platform, a means of cell delivery (reviewed in [115]), and a predictable regulatory framework. In this review, we have brought attention to the promise of MSCs as a therapy to improve cutaneous wound healing and the need for new technologies to overcome these barriers and enable the clinical use of MSCs in wound healing applications.

\section{Abbreviations}

ECM, extracellular matrix; FGF, fibroblast growth factor; G-CSF, granulocytecolony stimulating factor; HB-EGF, heparin bound epidermal growth factor; HGF, hepatocyte growth factor; IFN, interferon; IL, interleukin; MMP, matrix metalloproteinase; MSC, mesenchymal stem cell; PGE2, prostaglandin $E_{2}$; RNS, reactive nitrogen species; $\mathrm{ROS}$, reactive oxygen species; $S D F$, stromal cellderived factor; TGF, transforming growth factor; TNF, tumor necrosis factor; VEGF, vascular endothelial growth factor.

\section{Competing interests}

The authors declare that they have no competing interests.

\section{Acknowledgements}

Supported in part by the National Institutes of Health Intramural Research Program (Z01 AR41131) and from the Commonwealth of Pennsylvania Department of Health. Additional support provided by the Department of Defense Military Amputee Research Program at the Walter Reed Army Medical Center (Department of the Army, Grant No. P05-A011), the Peerreviewed Orthopedic Research Program (Department of the Army, Grants No. W81 XWH-10-2-0084 and W81XWH-10-2-0085), and the Defense Medical Research Development Program (Department of the Army, Grant No. D10_I_AR_J8_981), for which the U.S. Army Medical Research Acquisition Activity 820 Chandler Street, Fort Detrick MD 21702-5014 is the awarding and administering acquisition office. The views expressed in this manuscript are those of the authors alone and do not represent the views, policies or official positions of, nor should any official endorsement be inferred on the part of, the United States Government, the United States Army, the Uniformed Services University of the Health Sciences (USU), or the Department of Defense. Nor do they represent those of the National Institutes of Health or the Department of Health and Human Services. Figure one was produced using Sevier Medical Art. 


\section{Author details}

'Clinical and Experimental Orthopaedics Laboratory, Department of Surgery, Uniformed Services University, Bethesda, MD 20814, USA. ${ }^{2}$ The Henry M. Jackson Foundation for the Advancement of Military Medicine, Bethesda, MD 20817, USA. ${ }^{3}$ Orthopaedic Research Group, National Institute of Arthritis and Musculoskeletal and Skin Diseases, National Institutes of Health, Bethesda, MD 20892, USA. ${ }^{4}$ Center for Cellular and Molecular Engineering, Department of Orthopaedic Surgery, University of Pittsburgh School of Medicine, 450 Technology Drive, Room 221, Pittsburgh, PA 15219, USA.

Published: 31 May 2012

\section{References}

1. Martin P: Wound healing - aiming for perfect skin regeneration. Science 1997, 276:75-81.

2. Clark R: Wound repair overview and general considerations. In The Molecular and Cellular Biology of Wound Repair. Edited by Clark R. Plenum Press; 1996:3-50

3. Buchanan EP, Longaker MT, Lorenz HP: Fetal skin wound healing. Adv Clin Chem 2009, 48:137-161.

4. Velnar T, Bailey T, Smrkolj V: The wound healing process: an overview of the cellular and molecular mechanisms. J Int Med Res 2009, 37:1528-1542.

5. Rhett JM, Ghatnekar GS, Palatinus JA, O'Quinn M, Yost MJ, Gourdie RG: Novel therapies for scar reduction and regenerative healing of skin wounds. Trends Biotechnol 2008, 26:173-180.

6. Badiavas EV, Abedi M, Butmarc J, Falanga V, Quesenberry P: Participation of bone marrow derived cells in cutaneous wound healing. J Cell Physiol 2003, 196:245-250.

7. Salem HK, Thiemermann C: Mesenchymal stromal cells: current understanding and clinical status. Stem Cells 2010, 28:585-596.

8. Dominici M, Le Blanc K, Mueller I, Slaper-Cortenbach I, Marini F, Krause D, Deans R, Keating A, Prockop D, Horwitz E: Minimal criteria for defining multipotent mesenchymal stromal cells. The International Society for Cellular Therapy position statement. Cytotherapy 2006, 8:315-317.

9. Caplan Al, Dennis JE: Mesenchymal stem cells as trophic mediators. J Cell Biochem 2006, 98:1076-1084

10. Friedenstein AJ, Deriglasova UF, Kulagina NN, Panasuk AF, Rudakowa SF, Luria EA, Ruadkow IA: Precursors for fibroblasts in different populations of hematopoietic cells as detected by the in vitro colony assay method. Exp Hematol 1974, 2:83-92

11. Gimble JM, Guilak F: Adipose-derived adult stem cells: isolation, characterization, and differentiation potential. Cytotherapy 2003, 5:362-369.

12. Meliga E, Strem BM, Duckers HJ, Serruys PW: Adipose-derived cells. Cell Transplant 2007, 16:963-970.

13. Tuli R, Li WJ, Tuan RS: Current state of cartilage tissue engineering. Arthritis Res Ther 2003, 5:235-238.

14. Kuo CK, Tuan RS: Tissue engineering with mesenchymal stem cells. IEEE Eng Med Biol Mag 2003, 22:51-56.

15. Song L, Young NJ, Webb NE, Tuan RS: Origin and characterization of multipotential mesenchymal stem cells derived from adult human trabecular bone. Stem Cells Dev 2005, 14:712-721.

16. Tuli R, Tuli S, Nandi S, Wang ML, Alexander PG, Haleem-Smith H, Hozack WJ, Manner PA, Danielson KG, Tuan RS: Characterization of multipotential mesenchymal progenitor cells derived from human trabecular bone. Stem Cells 2003, 21:681-693.

17. Noth U, Osyczka A, Tuli R, Hickok N, Danielson K, Tuan R: Multilineage mesenchymal differentiation potential of human trabecular bone-derived cells. J Orthop Res 2002, 20:1060-1069.

18. Nakahara H, Dennis JE, Bruder SP, Haynesworth SE, Lennon DP, Caplan Al: In vitro differentiation of bone and hypertrophic cartilage from periostealderived cells. Exp Cell Res 1991, 195:492-503.

19. Choi Y-S, Noh S-E, Lim S-M, Lee C-W, Kim C-S, Im M-W, Lee M-H, Kim D-I: Multipotency and growth characteristic of periosteum-derived progenitor cells for chondrogenic, osteogenic, and adipogenic differentiation. Biotechnol Lett 2008, 30:593-601.

20. Jones EA, English A, Henshaw K, Kinsey SE, Markham AF, Emery P, McGonagle $D$ : Enumeration and phenotypic characterization of synovial fluid multipotential mesenchymal progenitor cells in inflammatory and degenerative arthritis. Arthritis Rheum 2004, 50:817-827.

21. Vandenabeele F, De Bari C, Moreels M, Lambrichts I, Dell'Accio F, Lippens PL, Luyten FP: Morphological and immunocytochemical characterization of cultured fibroblast-like cells derived from adult human synovial membrane. Arch Histol Cytol 2003, 66:145-153.

22. Fan J, Varshney RR, Ren L, Cai D, Wang D-A: Synovium-derived mesenchymal stem cells: A new cell source for musculoskeletal regeneration. Tissue Eng Part B 2009, 15:75-86.

23. Jo YY, Lee HJ, Kook SY, Choung HW, Park JY, Chung JH, Choung YH, Kim ES, Yang HC, Choung PH: Isolation and characterization of postnatal stem cells from human dental tissues. Tissue Eng 2007, 13:767-773.

24. Gay IC, Chen S, MacDougall M: Isolation and characterization of multipotent human periodontal ligament stem cells. Orthod Craniofac Res 2007, 10:149-160.

25. Janjanin S, Djouad F, Shanti RM, Baksh D, Gollapudi K, Prgomet D, Rackwitz L, Joshi AS, Tuan RS: Human palatine tonsil: a new potential tissue source of multipotent mesenchymal progenitor cells. Arthritis Res Ther 2008, 10:R83.

26. Shih YR, Kuo TK, Yang AH, Lee OK, Lee CH: Isolation and characterization of stem cells from the human parathyroid gland. Cell Prolif 2009, 42:461-470.

27. Jazedje T, Perin PM, Czeresnia CE, Maluf M, Halpern S, Secco M, Bueno DF, Vieira NM, Zucconi E, Zatz M: Human fallopian tube: a new source of multipotent adult mesenchymal stem cells discarded in surgical procedures. J Trans/ Med 2009, 7:46.

28. Nesti $L$, Jackson WM, Shanti RM, Koehler SM, Aragon AB, Bailey JR, Sracic MK Freedman BA, Giuliani JR, Tuan RS: Differentiation potential of multipotent progenitor cells derived from war-traumatized muscle tissue. J Bone Joint Surg Am 2008, 90:2390-2398.

29. Jackson WM, Aragon AB, Djouad F, Song Y, Koehler SM, Nesti $\sqcup$, Tuan RS: Mesenchymal progenitor cells derived from traumatized human muscle. J Tissue Eng Regen Med 2009, 3:129-138.

30. Baksh D, Yao R, Tuan RS: Comparison of proliferative and multilineage differentiation potential of human mesenchymal stem cells derived from umbilical cord and bone marrow. Stem Cells 2007, 25:1384-1392.

31. Lee OK, Kuo TK, Chen W-M, Lee K-D, Hsieh S-L, Chen T-H: Isolation of multipotent mesenchymal stem cells from umbilical cord blood. Blood 2004, 103:1669-1675.

32. Cetrulo CL Jr: Cord-blood mesenchymal stem cells and tissue engineering. Stem Cell Rev 2006, 2:163-168

33. Troyer DL, Weiss ML: Concise Review: Wharton's jelly-derived cells are a primitive stromal cell population. Stem Cells 2008, 26:591-599.

34. Huang G, Sonoyama W, Liu Y, Liu H, Wang S, Shi S: The hidden treasure in apical papilla: The potential role in pulp/dentin regeneration and BioRoot engineering. J Endodont 2008, 34:645-651.

35. Huang GT, Gronthos S, Shi S: Mesenchymal stem cells derived from dental tissues vs. those from other sources: their biology and role in regenerative medicine. J Dent Res 2009, 88:792-806.

36. Caplan Al: All MSCs are pericytes? Cell Stem Cell 2008, 3:229-230.

37. Kode JA, Mukherjee S, Joglekar MV, Hardikar AA: Mesenchymal stem cells: immunobiology and role in immunomodulation and tissue regeneration. Cytotherapy 2009, 11:377-391.

38. Ponte AL, Marais E, Gallay N, Langonne A, Delorme B, Herault O, Charbord P, Domenech J: The in vitro migration capacity of human bone marrow mesenchymal stem cells: comparison of chemokine and growth factor chemotactic activities. Stem Cells 2007, 25:1737-1745.

39. Sasaki M, Abe R, Fujita Y, Ando S, Inokuma D, Shimizu H: Mesenchymal stem cells are recruited into wounded skin and contribute to wound repair by transdifferentiation into multiple skin cell type. J Immuno/ 2008, 180:2581-2587.

40. Mishima Y, Lotz M: Chemotaxis of human articular chondrocytes and mesenchymal stem cells. J Orthop Res 2008, 26:1407-1412.

41. Hemeda H, Jakob M, Ludwig AK, Giebel B, Lang S, Brandau S: Interferongamma and tumor necrosis factor-alpha differentially affect cytokine expression and migration properties of mesenchymal stem cells. Stem Cells Dev 2010, 19:693-706.

42. Ortiz LA, Gambelli F, McBride C, Gaupp D, Baddoo M, Kaminski N, Phinney DG: Mesenchymal stem cell engraftment in lung is enhanced in response to bleomycin exposure and ameliorates its fibrotic effects. Proc Natl Acad SCiUSA 2003, 100:8407-8411.

43. Chen L, Tredget EE, Liu C, Wu Y: Analysis of allogenicity of mesenchymal stem cells in engraftment and wound healing in mice. PLoS One 2009, 4:e7119.

44. Deng W, Han Q, Liao L, Li C, Ge W, Zhao Z, You S, Deng H, Murad F, Zhao RC: Engrafted bone marrow-derived flk-(1+) mesenchymal stem cells regenerate skin tissue. Tissue Eng 2005, 11:110-119. 
45. Ishii G, Sangai T, Sugiyama K, Ito T, Hasebe T, Endoh Y, Magae J, Ochiai A: In vivo characterization of bone marrow-derived fibroblasts recruited into fibrotic lesions. Stem Cells 2005, 23:699-706.

46. Hannoush EJ, Sifri ZC, Elhassan IO, Mohr AM, Alzate WD, Offin M, Livingston $\mathrm{DH}$ : Impact of enhanced mobilization of bone marrow derived cells to site of injury. J Trauma 2011, 71:283-289; discussion 289-291.

47. Rasmusson I: Immune modulation by mesenchymal stem cells. Exp Cell Res 2006, 312:2169-2179.

48. Djouad F, Bouffi C, Ghannam S, Noel D, Jorgensen C: Mesenchymal stem cells: innovative therapeutic tools for rheumatic diseases. Nat Rev Rheumato/ 2009, 5:392-399.

49. Ren G, Zhang L, Zhao X, Xu G, Zhang Y, Roberts Al, Zhao RC, Shi Y: Mesenchymal stem cell-mediated immunosuppression occurs via concerted action of chemokines and nitric oxide. Cell Stem Cell 2008, 2:141-150.

50. Chamberlain G, Fox J, Ashton B, Middleton J: Concise review: Mesenchymal stem cells: their phenotype, differentiation capacity, immunological features, and potential for homing. Stem Cells 2007, 25:2739-2749.

51. Corcione A, Benvenuto F, Ferretti E, Giunti D, Cappiello V, Cazzanti F, Risso M, Gualandi F, Mancardi G, Pistoia V, Uccelli A: Human mesenchymal stem cells modulate B-cell functions. Blood 2006, 107:367-372.

52. Sotiropoulou P, Perez S, Gritzapis A, Baxevanis C, Papamichail M: Interactions between human mesenchymal stem cells and natural killer cells. Stem Cells 2006, 24:74-85.

53. Ashcroft GS, Yang X, Glick AB, Weinstein M, Letterio JL, Mizel DE, Anzano M, Greenwell-Wild T, Wahl SM, Deng C, Roberts AB: Mice lacking Smad3 show accelerated wound healing and an impaired local inflammatory response. Nat Cell Biol 1999, 1:260-266.

54. Redd MJ, Cooper L, Wood W, Stramer B, Martin P: Wound healing and inflammation: embryos reveal the way to perfect repair. Philos Trans $R$ SoC Lond B Biol Sci 2004, 359:777-784.

55. Martinez FO, Helming L, Gordon S: Alternative activation of macrophages: an immunologic functional perspective. Annu Rev Immuno/ 2009, 27:451-483.

56. Trautmann A, Toksoy A, Engelhardt E, Brocker EB, Gillitzer R: Mast cell involvement in normal human skin wound healing: expression of monocyte chemoattractant protein-1 is correlated with recruitment of mast cells which synthesize interleukin-4 in vivo. J Patho/ 2000, 190:100-106.

57. Stout RD: Editorial: macrophage functional phenotypes: no alternatives in dermal wound healing? J Leukoc Bio/ 2010, 87:19-21.

58. Marikovsky M, Breuing K, Liu PY, Eriksson E, Higashiyama S, Farber P, Abraham J, Klagsbrun M: Appearance of heparin-binding EGF-like growth factor in wound fluid as a response to injury. Proc Natl Acad Sci U S A 1993 90:3889-3893

59. Barrientos S, Stojadinovic O, Golinko MS, Brem H, Tomic-Canic M: Growth factors and cytokines in wound healing. Wound Repair Regen 2008, 16:585-601.

60. Németh K, Leelahavanichkul A, Yuen PS, Mayer B, Parmelee A, Doi K, Robey PG, Leelahavanichkul K, Koller BH, Brown JM, Hu X, Jelinek I, Star RA, Mezey E: Bone marrow stromal cells attenuate sepsis via prostaglandin $\mathrm{E}(2)$ dependent reprogramming of host macrophages to increase their interleukin-10 production. Nat Med 2009, 15:42-49.

61. Jarvinen L, Badri L, Wettlaufer S, Ohtsuka T, Standiford TJ, Toews GB, Pinsky DJ, Peters-Golden M, Lama VN: Lung resident mesenchymal stem cells isolated from human lung allografts inhibit T cell proliferation via a soluble mediator. J Immuno/ 2008, 181:4389-4396.

62. Djouad F, Charbonnier LM, Bouffi C, Louis-Plence P, Bony C, Apparailly F, Cantos C, Jorgensen C, Noel D: Mesenchymal stem cells inhibit the differentiation of dendritic cells through an interleukin-6-dependent mechanism. Stem Cells 2007, 25:2025-2032.

63. Zanone MM, Favaro E, Miceli I, Grassi G, Camussi E, Caorsi C, Amoroso A Giovarelli M, Perin PC, Camussi G: Human mesenchymal stem cells modulate cellular immune response to islet antigen glutamic acid decarboxylase in type 1 diabetes. J Clin Endocrinol Metab 2010, 95:3788-3797.

64. Aggarwal S, Pittenger M: Human mesenchymal stem cells modulate allogeneic immune cell responses. Blood 2005, 105:1815-1822.

65. Varin A, Gordon S: Alternative activation of macrophages: immune function and cellular biology. Immunobiology 2009, 214:630-641.

66. Benbernou N, Esnault S, Shin HC, Fekkar H, Guenounou M: Differential regulation of IFN-gamma, IL-10 and inducible nitric oxide synthase in human T cells by cyclic AMP-dependent signal transduction pathway. Immunology 1997, 91:361-368.

67. Moore KW, de Waal Malefyt R, Coffman RL, O'Garra A: Interleukin-10 and the interleukin-10 receptor. Annu Rev Immuno/ 2001, 19:683-765.

68. Sato Y, Ohshima T, Kondo T: Regulatory role of endogenous interleukin-10 in cutaneous inflammatory response of murine wound healing. Biochem Biophys Res Commun 1999, 265:194-199.

69. Reitamo S, Remitz A, Tamai K, Uitto J: Interleukin-10 modulates type collagen and matrix metalloprotease gene expression in cultured human skin fibroblasts. J Clin Invest 1994, 94:2489-2492.

70. Liechty KW, Kim HB, Adzick NS, Crombleholme TM: Fetal wound repair results in scar formation in interleukin-10-deficient mice in a syngeneic murine model of scarless fetal wound repair. J Pediatr Surg 2000, 35:866872; discussion 872-863.

71. Peranteau WH, Zhang L, Muvarak N, Badillo AT, Radu A, Zoltick PW, Liechty $\mathrm{KW}$ : IL-10 overexpression decreases inflammatory mediators and promotes regenerative healing in an adult model of scar formation. J Invest Dermatol 2008, 128:1852-1860.

72. Gordon A, Kozin ED, Keswani SG, Vaikunth SS, Katz AB, Zoltick PW, Favata M, Radu AP, Soslowsky LJ, Herlyn M, Crombleholme TM: Permissive environment in postnatal wounds induced by adenoviral-mediated overexpression of the anti-inflammatory cytokine interleukin-10 prevents scar formation. Wound Repair Regen 2008, 16:70-79.

73. Sato K, Ozaki K, Oh I, Meguro A, Hatanaka K, Nagai T, Muroi K, Ozawa K: Nitric oxide plays a critical role in suppression of T-cell proliferation by mesenchymal stem cells. Blood 2007, 109:228-234.

74. Poli G: Pathogenesis of liver fibrosis: role of oxidative stress. Mol Aspects Med 2000, 21:49-98.

75. Muriel P: Nitric oxide protection of rat liver from lipid peroxidation, collagen accumulation, and liver damage induced by carbon tetrachloride. Biochem Pharmacol 1998, 56:773-779.

76. Wink DA, Vodovotz Y, Grisham MB, DeGraffW, Cook JC, Pacelli R, Krishna M, Mitchell JB: Antioxidant effects of nitric oxide. Methods Enzymol 1999, 301:413-424

77. Beckman JS, Koppenol WH: Nitric oxide, superoxide, and peroxynitrite: the good, the bad, and ugly. Am J Physio/ 1996, 271:C1424-1437.

78. Ferrini MG, Vernet D, Magee TR, Shahed A, Qian A, Rajfer J, Gonzalez-Cadavid NF: Antifibrotic role of inducible nitric oxide synthase. Nitric Oxide 2002, 6:283-294

79. Li L, Zhang Y, Li Y, Yu B, Xu Y, Zhao S, Guan Z: Mesenchymal stem cell transplantation attenuates cardiac fibrosis associated with isoproterenolinduced global heart failure. Transp/ Int 2008, 21:1181-1189.

80. Chen L, Tredget EE, Wu PY, Wu Y: Paracrine factors of mesenchymal stem cells recruit macrophages and endothelial lineage cells and enhance wound healing. PLoS One 2008, 3:e1886.

81. Li L, Zhang S, Zhang Y, Yu B, Xu Y, Guan Z: Paracrine action mediate the antifibrotic effect of transplanted mesenchymal stem cells in a rat model of global heart failure. Mol Biol Rep 2009, 36:725-731.

82. Mou S, Wang Q, Shi B, Gu L, Ni Z: Hepatocyte growth factor suppresses transforming growth factor-beta-1 and type III collagen in human primary renal fibroblasts. Kaohsiung J Med Sci 2009, 25:577-587.

83. Schievenbusch S, Strack I, Scheffler M, Wennhold K, Maurer J, Nischt R, Dienes HP, Odenthal M: Profiling of anti-fibrotic signaling by hepatocyte growth factor in renal fibroblasts. Biochem Biophys Res Commun 2009, 385:55-61.

84. Inagaki Y, Higashi K, Kushida M, Hong YY, Nakao S, Higashiyama R, Moro T, Itoh J, Mikami T, Kimura T, Shiota G, Kuwabara I, Okazaki I: Hepatocyte growth factor suppresses profibrogenic signal transduction via nuclear export of Smad3 with galectin-7. Gastroenterology 2008, 134:1180-1190.

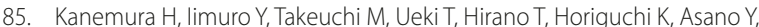
Fujimoto J: Hepatocyte growth factor gene transfer with naked plasmid DNA ameliorates dimethylnitrosamine-induced liver fibrosis in rats. Hepatol Res 2008, 38:930-939.

86. Bevan D, Gherardi E, Fan TP, Edwards D, Warn R: Diverse and potent activities of HGF/SF in skin wound repair. J Pathol 2004, 203:831-838.

87. Gille J, Khalik M, Konig V, Kaufmann R: Hepatocyte growth factor/scatter factor (HGF/SF) induces vascular permeability factor (VPF/VEGF) expression by cultured keratinocytes. J Invest Dermato/ 1998, 111:1160-1165.

88. Estes JM, Vande Berg JS, Adzick NS, MacGillivray TE, Desmouliere A, Gabbiani $\mathrm{G}$ : Phenotypic and functional features of myofibroblasts in sheep fetal 
wounds. Differentiation 1994, 56:173-181.

89. Shannon DB, McKeown ST, Lundy FT, Irwin CR: Phenotypic differences between oral and skin fibroblasts in wound contraction and growth factor expression. Wound Repair Regen 2006, 14:172-178.

90. Shukla MN, Rose JL, Ray R, Lathrop KL, Ray A, Ray P: Hepatocyte growth factor inhibits epithelial to myofibroblast transition in lung cells via Smad7. Am J Respir Cell Mol Biol 2009, 40:643-653.

91. McAnulty RJ: Fibroblasts and myofibroblasts: their source, function and role in disease. Int J Biochem Cell Biol 2007, 39:666-671.

92. Opalenik SR, Davidson JM: Fibroblast differentiation of bone marrowderived cells during wound repair. Faseb J 2005, 19:1561-1563.

93. Abe R, Donnelly SC, Peng T, Bucala R, Metz CN: Peripheral blood fibrocytes: differentiation pathway and migration to wound sites. J Immuno/ 2001, 166:7556-7562.

94. Bucala R, Spiegel LA, Chesney J, Hogan M, Cerami A: Circulating fibrocytes define a new leukocyte subpopulation that mediates tissue repair. Mol Med 1994, 1:71-81.

95. Yang J, Dai C, Liu Y: A novel mechanism by which hepatocyte growth factor blocks tubular epithelial to mesenchymal transition. J Am Soc Nephro/ 2005, 16:68-78.

96. Zhang A, Wang MH, Dong Z, Yang T: Prostaglandin E2 is a potent inhibitor of epithelial-to-mesenchymal transition: interaction with hepatocyte growth factor. Am J Physiol Renal Physiol 2006, 291:F1323-1331.

97. Smith AN, Willis E, Chan VT, Muffley LA, Isik FF, Gibran NS, Hocking AM: Mesenchymal stem cells induce dermal fibroblast responses to injury. Exp Cell Res 2010, 316:48-54.

98. Brown LF, Yeo KT, Berse B, Yeo TK, Senger DR, Dvorak HF, van de Water L: Expression of vascular permeability factor (vascular endothelial growth factor) by epidermal keratinocytes during wound healing. J Exp Med 1992, 176:1375-1379.

99. Gruber R, Kandler B, Holzmann P, Vogele-Kadletz M, Losert U, Fischer MB, Watzek G: Bone marrow stromal cells can provide a local environment that favors migration and formation of tubular structures of endothelial cells. Tissue Eng 2005, 11:896-903

100. Kaigler D, Krebsbach PH, Polverini PJ, Mooney DJ: Role of vascular endothelial growth factor in bone marrow stromal cell modulation of endothelial cells. Tissue Eng 2003, 9:95-103.

101. Lozito TP, Taboas JM, Kuo CK, Tuan RS: Mesenchymal stem cell modification of endothelial matrix regulates their vascular differentiation. J Cell Biochem 2009, 107:706-713.

102. Kato J, Tsuruda T, Kita T, Kitamura K, Eto T: Adrenomedullin: a protective factor for blood vessels. Arterioscler Thromb Vasc Biol 2005, 25:2480-2487.

103. Renault MA, Roncalli J, Tongers J, Misener S, Thorne T, Jujo K, Ito A, Clarke T, Fung C, Millay M, Kamide C, Scarpelli A, Klyachko E, Losordo DW: The Hedgehog transcription factor Gli3 modulates angiogenesis. Circ Res 2009, 105:818-826.

104. Bianco P, Robey P, Simmons P: Mesenchymal stem cells: revisiting history, concepts, and assays. Cell Stem Cell 2008, 2:313-319.

105. Sorrell JM, Baber MA, Caplan Al: Influence of adult mesenchymal stem cells on in vitro vascular formation. Tissue Eng Part A 2009, 15:1751-1761.

106. Au P, Tam J, Fukumura D, Jain RK: Bone marrow-derived mesenchymal stem cells facilitate engineering of long-lasting functional vasculature. Blood 2008, 111:4551-4558.

107. Yamaguchi Y, Kubo T, Murakami T, Takahashi M, Hakamata Y, Kobayashi E, Yoshida S, Hosokawa K, Yoshikawa K, Itami S: Bone marrow cells differentiate into wound myofibroblasts and accelerate the healing of wounds with exposed bones when combined with an occlusive dressing. Br J Dermatol 2005, 152:616-622

108. Fu X, Fang L, Li X, Cheng B, Sheng Z: Enhanced wound-healing quality with bone marrow mesenchymal stem cells autografting after skin injury. Wound Repair Regen 2006, 14:325-335.

109. Lozito TP, Kuo CK, Taboas JM, Tuan RS: Human mesenchymal stem cells express vascular cell phenotypes upon interaction with endothelial cell matrix. J Cell Biochem 2009, 107:714-722.

110. Wu Y, Chen L, Scott PG, Tredget EE: Mesenchymal stem cells enhance wound healing through differentiation and angiogenesis. Stem Cells 2007, 25:2648-2659.

111. Bunnell BA, Betancourt AM, Sullivan DE: New concepts on the immune modulation mediated by mesenchymal stem cells. Stem Cell Res Ther 2010, $1: 34$.

112. Raicevic G, Rouas R, Najar M, Stordeur P, Boufker HI, Bron D, Martiat P Goldman M, Nevessignsky MT, Lagneaux L: Inflammation modifies the pattern and the function of Toll-like receptors expressed by human mesenchymal stromal cells. Hum Immuno/ 2010, 71:235-244.

113. Jackson WM, Nesti LJ, Tuan RS: Clinical translation of wound healing therapies based on mesenchymal stem cells. Stem Cells Trans Med 2012, in press

114. ClinicalTrials.gov [http://www.clinicaltrials.gov]

115. Sorrell JM, Caplan Al: Topical delivery of mesenchymal stem cells and their function in wounds. Stem Cell Res Ther 2010, 1:30

116. Javazon EH, Keswani SG, Badillo AT, Crombleholme TM, Zoltick PW, Radu AP, Kozin ED, Beggs K, Malik AA, Flake AW: Enhanced epithelial gap closure and increased angiogenesis in wounds of diabetic mice treated with adult murine bone marrow stromal progenitor cells. Wound Repair Regen 2007, 15:350-359.

117. Nie C, Yang D, Xu J, Si Z, Jin X, Zhang J: Locally administered adiposederived stem cells accelerate wound healing through differentiation and vasculogenesis. Cell Transplant 2010, 20:205-216.

118. Stoff A, Rivera AA, Sanjib Banerjee N, Moore ST, Michael Numnum T, Espinosade-Los-Monteros A, Richter DF, Siegal GP, Chow LT, Feldman D, Vasconez LO, Michael Mathis J, Stoff-Khalili MA, Curiel DT: Promotion of incisional wound repair by human mesenchymal stem cell transplantation. Exp Dermatol 2009, 18:362-369.

119. Egana JT, Fierro FA, Kruger S, Bornhauser M, Huss R, Lavandero S, Machens HG: Use of human mesenchymal cells to improve vascularization in a mouse model for scaffold-based dermal regeneration. Tissue Eng Part A 2009, 15:1191-1200.

120. Falanga V, Iwamoto S, Chartier M, Yufit T, Butmarc J, Kouttab N, Shrayer D, Carson P: Autologous bone marrow-derived cultured mesenchymal stem cells delivered in a fibrin spray accelerate healing in murine and human cutaneous wounds. Tissue Eng 2007, 13:1299-1312.

121. McFarlin K, Gao X, Liu YB, Dulchavsky DS, Kwon D, Arbab AS, Bansal M, LiY, Chopp M, Dulchavsky SA, Gautam SC: Bone marrow-derived mesenchymal stromal cells accelerate wound healing in the rat. Wound Repair Regen 2006, 14:471-478.

doi: $10.1186 /$ scrt111

Cite this article as: Jackson WM, et al.: Mesenchymal stem cell therapy for attenuation of scar formation during wound healing. Stem Cell Research \& Therapy 2012, 3:20. 